\title{
PERANAN KELOMPOK PETERNAK DALAM MENUNJANG KEBERHASILAN USAHA SAPI POTONG DI KABUPATEN BOALEMO
}

\author{
The Role of Cattle Breeders in Supporting the Success of Beef Cattle Business in \\ Boalemo Regency
}

\author{
Hasnawati ${ }^{1}$, Anna Fariyanti², Sri Mulatsih ${ }^{3}$ \\ 1 Staf Dinas Peternakan dan Perkebunan Provinsi Gorontalo. Email: hasnawatinompo@yahoo.com \\ 2Staff Pengajar Departemen Agribisnis. Fakultas Ekonomi dan Manajemen.Institut Pertanian Bogor. \\ E-mail: a_fariyanti@yahoo.com
}

3Staff Pengajar Departemen Ilmu Ekonomi. Fakultas Ekonomi dan Manajemen.Institut Pertanian Bogor. E-mail: mulatsupardi@gmail.com

\begin{abstract}
This research was carried out in Wonosari District, Boalemo Regency, Gorontalo Province on April - July 2014. This research aimed: (1) to analyze the factors influencing the earnings of the cattle breeders in Boalemo Regency, (2) to analyze the performance of the cattle breeders towards the success of beef cattle business in Boalemo Regency, (3) to formulate the strategy to increase the cattle breeders' role in supporting the business of beef cattle in Boalemo Regency. This research used the method of purposive sampling, and the criteria of breeders used were group of cattle breeders and non-group of cattle breeders (independent cattle breeders). The number of sample used in the survey was 30 members of cattle breeder group and 20 respondents from non-group of cattle breeders. The analysis instruments used were (1) the analysis of beef cattle business, (2) the analysis of Multiple Linear Regression, (3) the Importance Performance Analysis (IPA).The analysis result of the earning in 3,76 AU (animal unit) scale was $R p$ 3.010.849 year and non-group in 3,48 AU scale was $R p$ 3.983.934 year. The factor influencing farmer income are the number of bull, number of cow, and forage consumtion. The result of Importance Performance Analysis showed that the atribute in the first quadrant had the high level of importantance, but low performance, i.e. (1) getting the additional feed/beef cattle business consentrate, (2) the skill of group member, (3) the facility of means and infrastructure supporting the animal husbandary, (4) obtaining the financial for beef cattle business, and (5) the organization establishment of beef cattle group members.
\end{abstract}

Key words: group role, double linear regression, importance performance analysis, policy strategy, Boalemo regency

\begin{abstract}
ABSTRAK
Penelitian dilaksanakan di Kecamatan Wonosari Kabupaten Boalemo Provinsi Gorontalo pada bulan April sampai Juli 2014. Penelitian ini bertujuan : (1) Menganalisis faktor-faktor yang mempengaruhi pendapatan kelompok peternak sapi potong di Kabupaten Boalemo, (2) Menganalisis kinerja kelompok peternak terhadap keberhasilan usaha sapi potong di Kabupaten Boalemo, (3) Merumuskan strategi untuk meningkatkan peran kelompok peternak dalam menunjang usaha sapi potong di Kabupaten Boalemo. Pengambilan sampel secara purposive sampling,sampel dalam survey terdiri dari 30 anggota kelompok peternak dan 20 peternak non anggota kelompok. Alat analisis yang digunakan yaitu; (1) Analisis pendapatan usaha ternak, (2) Analisis Regresi Linier Berganda, (3) Importance Performance Analysis (IPA). Pendapatan usaha pembibitan sapi potong pada kelompok peternak skala 3,76 ST sebesar Rp 3.010.849 /tahun dan peternak non kelompok skala 3,48 ST sebesar Rp 3.983.934 /tahun. Factor yang mempengaruhi pendapatan peternak adalah jumlah pejantan dan induk sapi yang dimiliki serta pemberian pakan hijauan. Hasil Importance Performance Analysis menujukan bahwa atribut yang berada pada kuadran pertama memiliki tingkat kepentingan yang tinggi namun kinerjanya
\end{abstract}


masih rendah, yaitu (1) memperoleh pakan konsentrat, (2) Keterampilan anggota kelompok, (3) Fasilitas sarana dan prasarana pendukung peternakan, (4) Memperoleh modal usaha beternak sapi potong, dan (5) Pembinaan Kelembagaan Peternak Sapi Potong.

Kata Kunci: Peranan Kelompok, Regresi Linier Berganda, Importance Performance Analysis, Strategi Kebijakan, Kabupaten Boalemo

\section{PENDAHULUAN}

\section{Latar Belakang}

Peranan kelompok peternak sangat strategis dalam pengembangan usaha peternakan sapi potong. Sapi potong merupakan komoditas sub sektor peternakan yang sangat potensial. Hal ini dapat dilihat dari tingginya permintaan produk peternakan yang semakin naik seiring dengan bertambahnya jumlah penduduk serta meningkatnya pengetahuan dan kesadaran masyarakat tentang pentingnya mengkonsumsi pangan yang bergizi. Jumlah penduduk Provinsi Gorontalo 1.040 .164 jiwa dengan konsumsi daging 0,3 gram/hari/kapita dengan peningkatan populasi ternak sapi sekitar 4 persen per tahun (BPS 2013) Dalam rangka mendukung Program Swasembada daging Sapi diperlukan ketersediaan bibit sapi potong yang berkelanjutan. Untuk memenuhi ketersediaan bibit sapi potong perlu dilakukan program perbibitan sapi dalam suatu kawasan, yang sebagian besar dikelola masyarakat. Kegiatan perbibitan dengan tujuan meningkatkan produktivitas dan populasi ternak bibit melalui pemberdayaan kelompok (Direktorat Jenderal Peternakan 2013).

Peran kelompok peternak dalam aspek teknologi produksi, kelompok peternak harus mampu menerapkan catur usaha dengan pemilihan bibit bermutu, perbaikan mutu pakan dan teknik pemeliharaan serta peningkatan kualitas kesehatan ternak. Dalam aspek sosial-ekonomi kelompok peternak berperan untuk memperkuat kelembagaan dan jaringan pemasaran (Muhsis 2007).

Provinsi Gorontalo dengan luas wilayah $12.435 \mathrm{~km}^{2}$ memiliki potensi sumberdaya alam yang layak untuk pengembangan peternakan sapi potong dengan jumlah populasi ternak 174.858 ekor pada tahun 2013 (BPS 2013). Pengembangan peternakan sapi potong tersebut perlu didukung dengan kebijakan pemerintah tentang pemberdayaan kelompok pada usaha pembibitan sapi potong. Kebijakan Pemerintah Kabupaten Boalemo Provinsi Gorontalo SK Bupati Boalemo No 164 Tahun 2014 tentang menetapkan Kecamatan Wonosari sebagai pusat perbibitan Sapi di perdesaan (Village Breeding Centre) dengan melibatkan kelompok peternak. Pembinaan kelompok peternak sapi potong ditujukan untuk kemandirian dan ketangguhan kelompok peternak sebagai subyek pembangunan dan mendapatkan nilai tambah pendapatan usaha ternak. Usaha yang dilakukan kelompok peternak diharapkan terjadi keterpaduan usaha mulai dari penanganan budidaya sampai pada pemasaran hasil. Dari latar belakang diatas, penting dilakukan kajian "Peranan Kelompok dalam Menunjang Keberhasilan Sapi Potong di Kabupaten Boalemo.

\section{METODE PENELITIAN}

\section{Lokasi dan Waktu Penelitian}

Lokasi Penelitian dilaksanakan di Kecamatan Wonosari Kabupaten Boalemo Provinsi Gorontalo. 
Penelitian dilaksanakan dari bulan April sampai Juli 2014.

\section{Jenis dan Sumber Data}

Data yang digunakan dalam penelitian ini terdiri atas data primer dan data sekunder. Penelitian ini menggunakan metode pengambilan sampel secara purposive sampling dengan kriteria peternak yang menjadi anggota kelompok dan non anggota kelompok. Banyaknya sampel dalam survey yang digunakan adalah 30 peternak anggota kelompok dan 20 peternak non anggota kelompok. Data yang dikumpulkan adalah karakteristik peternak dan penggunaan sarana produksi usaha peternakan, serta persepsi anggota terhadap kinerja kelompok.

\section{Metode Pengolahan dan Analisis Data}

Pengolahan data dilakukan dengan analisis deskriptif, Analisis Pendapatan Usaha ternak, Analisis Regresi Linier Berganda dan Importance Performance Analysis (IPA). Analisis deskriptif menyajikan data menggunakan tabel, frekuensi dan persentase. Analisis deskriptif untuk menggambarkan peternak di Kecamatan Wonosari Kabupaten Boalemo.

\section{HASIL DAN PEMBAHASAN}

\section{Deskripsi Usaha Ternak Sapi Potong}

Deskripsi usaha ternak sapi potong di Kecamatan Wonosari Kabupaten Boalemo diantaranya pengalaman beternak, kelahiran anak betina, kelahiran anak jantan, kematian ternak, hijauan pakan ternak, pakan konsentrat, biaya obat,vaksin dan vitamin, tenaga kerja dan dummy kelompok (Tabel 1).

Tabel 1. Deskripsi Usaha Ternak Sapi Potong Di Kecamatan Wonosari Kabupaten Boalemo

\begin{tabular}{lrrrr}
\hline \multicolumn{1}{c}{ Variabel } & Kisaran (Range) & Rataan (Mean) & \multicolumn{2}{c}{ Standar deviasi } \\
& & & Nilai & $\%$ \\
\hline Lama beternak (tahun) & $3-15$ & 6,73 & 3,29 & 0,49 \\
Kelahiran anak jantan (ST/Th) & $0-2$ & 0,28 & 0,43 & 1,51 \\
Kelahiran anak betina (ST/Th) & $0-1$ & 0,27 & 0,34 & 1,28 \\
Biaya Obat,Vaksin,Vitamin & $84-84651$ & 773,78 & 846,11 & 1,09 \\
(Rp/TH) & $0,38-2$ & 0,94 & 0,35 & 0,37 \\
Tenaga Kerja (HOK)/hari & & &
\end{tabular}

Pada variabel lama beternak sapi potong (tahun) nilai terkecilnya adalah 3 sedangkan nilai terbesar adalah 15 . Hal ini menunjukkan bahwa pengalaman peternak dalam Usaha ternak sapi potong di kelompok peternak dan peternak non kelompok terendah adalah 3 tahun dan tertinggi 15 tahun. Nilai mean (rataan) sebesar 6,73 menunjukkan bahwa rata-rata pengalaman peternak sapi potong yakni 6,73 tahun dan nilai standar deviasi sebesar 3,29 menujukkan variasi yang terdapat dalam variabel lama beternak sapi potong. Semakin tinggi standar deviasi, maka semakin beragam pengalaman beternak sapi potong (Tabel 1).

Pada variabel kelahiran anak jantan (ST), hasil statistik (Tabel 1) menunjukkan bahwa kelahiran anak jantan dalam 1 tahun pada Usaha ternak sapi potong sebesar 1,51 persen Nilai mean (rataan) kelahiran anak jantan sebesar 0,28 ST/peternak dan standar deviasinya sebesar 0,429 yang menunjukkan variasi dalam jumlah kelahiran anak jantan.

Pada variabel kelahiran anak betina, hasil statistik (Tabel 1) 
menunjukkan kisaran $0-1$ kelahiran dalam 1 tahun. Nilai mean (rataan) sebesar 0,27 ST/tahun, jadi dalam satu tahun induk melahirkan 1 ekor $(0,25$ ST) anak betina. Standar deviasinya sebesar 1,28 persen yang menunjukkan variasi dalam kelahiran anak betina.

\section{Deskripsi Kepemilikan Ternak Sapi Potong}

Berdasarkan Tabel 2 komposisi kepemilikan ternak sapi di Kecamatan Wonosari pada kelompok peternak sekitar 3,76 ST. Dalam upaya pengembangan ternak sapi potong di wilayah Kecamatan Wonosari pemerintah daerah menekankan ke arah pengembangan pola breeding/ pembibitan sapi Bali. Kepemilikan sapi potong sebesar 3,76 ST per peternak sangat menunjang keberhasilan pengembangan pembibitan sapi Bali. Persentase kepemilikan sapi betina dewasa (induk) sebesar 53 persen, jantan dewasa 19 persen, jantan muda 6 persen, betina muda 59 persen, pedet jantan 9 persen dan betina 8 persen.

Tabel 2. Komposisi Kepemilikan Ternak Sapi Per Responden Kelompok Peternak Di Kecamatan Wonosari Kabupaten Boalemo

\begin{tabular}{lcc}
\hline Pemilikan Sapi & $\begin{array}{c}\text { Satuan } \\
\text { Ternak }\end{array}$ & Persentase \\
\hline Jantan Dewasa & 0,70 & 19 \\
Betina Dewasa & 2,00 & 53 \\
Jantan Muda & 0,22 & 6 \\
Betina Muda & 0,20 & 5 \\
Anak Jantan & 0,33 & 9 \\
Anak Betina & 0,31 & 8 \\
\hline \multicolumn{1}{c}{ Total } & 3,76 & 100 \\
\hline
\end{tabular}

\section{Pendapatan Kelompok Peternak dan Non Kelompok Peternak Sapi Potong di Kecamatan Wonosari Kabupaten Boalemo}

Kegiatan pengembangan sapi potong pada kelompok peternak di Kecamatan Wonosari Kabupaten
Boalemo pada dasarnya adalah kegiatan yang memiliki beberapa tujuan diantaranya untuk pengembangan pembibitan ternak, budidaya ternak, pengawasan penyakit ternak, pengelolaan serta pemasaran hasil ternak dan pemanfaatan hasil sampingan ternak baik kompos, hasil olahan seperti krupuk kulit, juga untuk tenaga kerja membajak sawah/kebun. Tujuan peternak memelihara ternak sapi juga merupakan tabungan, yang sewaktu-waktu dapat dijual apabila ada kebutuhan ekonomi keluarga yang mendesak. Pendapatan anggota kelompok peternak sapi potong disajikan pada Tabel 3.

Tabel 3. Pendapatan anggota kelompok peternak sapi potong skala 3,76 ST periode 1 tahun di Kecamatan Wonosari Kabupaten Boalemo

\begin{tabular}{llr}
\hline \multicolumn{1}{c}{ Uraian } & \multicolumn{1}{c}{ Nilai $(\mathrm{Rp})$} \\
\hline I & Penerimaan & \\
& Nilai awal ternak & $(5.951 .035)$ \\
& Nilai penjualan & 5.876 .495 \\
& Nilai pembelian & $(3.150 .000)$ \\
& Nilai akhir ternak & 7.475 .467 \\
& 4.250 .909 \\
& Pupuk kandang & 127.360 \\
& Total penerimaan & $\mathbf{4 . 3 7 8 . 2 6 9}$ \\
\hline II & Biaya & \\
& Hijauan pakan & \\
& ternak & 373.928 \\
& Pakan konsentrat & 649.370 \\
& Biaya obat/vaksin & \\
& /vitamin & 91.500 \\
& Kandang & \\
& (penyusutan) & 202.622 \\
& Peralatan & \\
& (penyusutan) & 50.000 \\
& Total biaya & $\mathbf{1 . 3 6 7 . 4 2 0}$ \\
\hline III & Pendapatan & 3.010 .849 \\
\hline
\end{tabular}

Pada Tabel 3 biaya produksi hijauan sebesar Rp373.928 per peternak, pakan konsentrat sebesar Rp649.370 per peternak. Untuk pengobatan ternak dan vaksin disuplai dari Dinas Peternakan dan Kesehatan Hewan Kabupaten Boalemo serta Dinas Peternakan Provinsi Gorontalo. Kisaran 
biaya Obat dan vaksin Rp 91.500 per peternak. Biaya penanaman bibit hijauan sekitar Rp 7.486 per peternak dan pupuk urea sekitar 0,5 gram dengan luas lahan yang dimiliki sekitar 10-25 $\mathrm{m}^{2}$. Biaya penyusutan kandang dan peralatan sekitar Rp 50.000 per peternak. Menurut Soeharjo dan Patong (1973) dalam Wijaya (2002), bahwa besarnya pendapatan yang diperoleh peternak merupakan salah satu indikator penting yang menjadi motivasi peternak dalam memilih Usaha ternak. Pendapatan Usaha ternak adalah selisih antara penerimaan Usaha ternak, baik tunai maupun tidak tunai, dengan biaya total yang dikeluarkan untuk keperluan operasional Usaha ternak.

Pada umumnya pemeliharaan sapi di Kecamatan Wonosari secara semi intensif, dimana sumber hijauan berasal dari padang penggembalaan dan disediakan oleh peternak. Pakan tambahan berupa konga/dedak, jagung. Menurut responden peternak sumber hijauan cukup mudah diperoleh. Peternak menanam rumput gajah dan hijauan lainnya (rumput lapangan, rumput benggala) dan tersedia cukup banyak di padang penggembalaan. Akan tetapi untuk memperoleh konsentrat agak sulit, mereka hanya memanfaatkan limbah jagung ataupun hasil panen padi (dedak/konga).

Hasil analisis usaha pendapatan sapi potong skala 3,76 ST sebesar Rp 3.010.849 per peternak/tahun dan jika dikonversikan per bulan maka rata-rata pendapatan per bulan sebesar Rp 312.000 per peternak. Jika melihat UMP Provinsi Gorontalo tahun $2013 \mathrm{Rp}$ 1.175.000 per bulan berdasar UU No 13 tahun 2013 tentang ketenagakerjaan (BPS 2013), sehingga pendapatan peternak sebesar Rp 312.000 masih jauh dari upah minimum, sehingga tingkat kesejahteraan peternak masih rendah. Sifat usaha yang dilakukan peternak pembibitan untuk tujuan sebagai tabungan dan usaha sampingan

menyebabkan peternak kurang memperhatikan faktor efisiensi usaha, sehingga dari hasil analisis finansial tidak menunjukkan profitabilitas yang layak secara ekonomi. Keuntungan diperoleh berdasarkan biaya tunai, artinya penggunaan tenaga kerja dan input lainnya yang tidak dibeli secara tunai tidak diperhitungkan dalam analisis.

Berdasarkan Tabel 4 dijelaskan penerimaan peternak non anggota kelompok $\mathrm{Rp} 5.514 .540$, total biaya $\mathrm{Rp}$ 1.531.605, sehingga pendapatan yang diperoleh $\mathrm{Rp}$ 3.982.934. Sedangkan pendapatan yang diperoleh pada kelompok peternak yaitu $\mathrm{Rp} 3.010 .849$. Terdapat perbedaan selisih pendapatan sekitar Rp 972.085. Dari hasil analisis keuntungan yang telah dilakukan, dapat disimpulkan bahwa usaha ternak yang non kelompok memperoleh pendapatan lebih tinggi dibandingkan kelompok. Ini menunjukkan bahwa keikutsertaan dalam kelompok bukan merupakan jaminan usaha ternak akan memperoleh pendapatan yang lebih tinggi, Permasalahannya adalah kelompok peternak di Kecamatan Wonosari masih belum mampu menjalankan perannya dengan baik (ditinjau dari keterampilan anggota kelompok) dan bisa dilihat dari proses belajar-mengajar, sistem, kerjasama yang kinerjanya masih perlu ditingkatkan.

Tabel 4. Pendapatan Peternak Non Kelompok skala 3,48 ST periode 1 tahun di Kecamatan Wonosari Kabupaten Boalemo

\begin{tabular}{llr}
\hline \multicolumn{1}{c}{ Uraian } & \multicolumn{1}{c}{ Nilai (Rp) } \\
\hline I & Penerimaan & \\
& Nilai awal ternak & $(4.854 .495)$ \\
& Nilai penjualan & 8.451 .786 \\
& Nilai pembelian & $(3.750 .000)$ \\
Nilai akhir ternak & 5.452 .249 \\
& 5.299 .540 \\
& 215.000 \\
& Pupuk kandang & 5.514 .540 \\
\hline Total penerimaan & \\
\hline II & Biaya & \\
& Hijauan pakan ternak & 583.770
\end{tabular}




\begin{tabular}{llr}
\hline \hline Uraian & \multicolumn{1}{c}{ Nilai (Rp) } \\
\hline & Pakan konsentrat & 808.058 \\
& Biaya obat/vaksin/ & \\
vitamin & 39.928 \\
& Kandang (penyusutan) & 80.000 \\
& Peralatan (penyusutan) & 19.850 \\
& Total Biaya & 1.531 .605 \\
\hline III & Pendapatan & 3.982 .934 \\
\hline & Perbedaan penerimaan pada
\end{tabular}

anggota kelompok peternak dengan non anggota kelompok, disebabkan anggota kelompok peternak orientasi usaha ke arah pembibitan sapi potong, disamping itu penjualan ternak masih rendah dikarenakan terdapat kewajiban untuk menggulirkan ternak ke kelompok lainnya. Sedangkan untuk peternak non kelompok, Usaha ternak dengan pola campuran antara pembibitan dan penggemukan. Penjualan sapi umumnya berdasarkan berat badan. Semakin berat maka semakin mahal harga sapi. Penaksiran harga disesuaikan dengan harga sapi yang sedang berlaku di pasaran. Kisaran harga sapi di Kec. Wonosari Kab. Boalemo, harga pejantan $\mathrm{Rp}$ 8.261.905/ekor, harga induk $\mathrm{Rp}$ 6.080.645/ekor, harga jantan muda Rp 4.807.692/ekor, betina muda $\mathrm{Rp}$ 4.666.667/ekor, jantan anak $\mathrm{Rp}$ 2.617.647/ekor, dan harga betina anak Rp 1.656.250/ekor. Umumnya peternak jarang menjual sapi dengan harga karkas, karena karkas biasanya ditentukan oleh pemotong. Peternak harus mampu menganalisis berat badan sapi agar mendapat keuntungan yang besar dan tidak terkecoh dengan harga penawaran pedagang ternak. Harga sapi menjadi mahal seiring dengan mahalnya harga daging sapi di pasaran Kabupaten Boalemo dan di Kota Gorontalo yang mencapai Rp 100.000 per kg. Menurut Purbowati dan Rianto (2009), di dalam usaha sapi potong manajemen pemasaran merupakan proses kegiatan atau aktivitas yang memiliki porsi cukup penting meliputi pengumpulan informasi pasar, penyimpanan, pengangkutan dan penjualan. Pada 
pendapatan perlu ditingkatkan dengan bantuan modal berupa ternak sapi dan kemudahan dalam akses kredit.

Hasil penelitian Rahmanto (2004), bahwa hasil analisis usaha ternak sapi bakalan peternak menunjukkan bahwa pembudidayaan ternak sapi bakalan secara ekonomi kurang menguntungkan. Jika semua input diperhitungkan sebagai korbanan biaya atas pembelian faktor produksi dan peternak menerima revenue atas penjualan semua output, maka keuntungan bersih yang diterima peternak adalah negatif, atau merugi sebesar Rp2,6 juta 1 ekor ternak selama 1 tahun pemeliharaan bakalan. Jika korbanan biaya dan revenue peternak hanya didasarkan pada pengeluaran dan penerimaan tunai, keuntungan peternak bisa mencapai sekitar Rp1,0 juta dengan 1 ekor ternak.

Apabila ditinjau dari sisi pendapatan dan tingkat upah kerja di tingkat provinsi, baik kelompok peternak maupun non kelompok peternak belum memperoleh pendapatan yang sesuai. Permasalahannya adalah rendahnya tingkat pendapatan yang diperoleh kelompok peternak sapi potong disebabkan oleh sifat usaha yang belum berorientasi bisnis. Keterampilan anggota kelompok perlu ditingkatkan karena kinerja masih rendah, yang dapat ditinjau dari hasil Importance Performance Analysis (IPA), sehingga diperlukan pembinaan yang lebih terarah agar usaha sapi potong sebagai usaha pokok. Menurut Soehadji (1995) tipologi usaha ternak di Indonesia berdasarkan skala usahanya menjadi empat yaitu: pertama, usaha ternak sebagai sambilan dengan pilihan komoditas pendukung pertanian (kungtan), kedua usaha ternak sebagai cabang usaha dengan pilihan komoditas campuran, ketiga usaha ternak sebagai usaha pokok dengan pilihan komoditas tunggal berupa ternak, dan keempat usaha ternak sebagai industri dengan pilihan komoditas $100 \%$ merupakan pilihan yang dianggap secara bisnis menguntungkan. Oleh karena itu berdasarkan tipologi usaha tersebut tingkat pendapatan yang diperoleh oleh peternak juga menjadi beragam (Gambar 2). Untuk meningkatkan pendapatan Usaha ternak di peternak non kelompok dan yang ikut kelompok perlu meningkatkan ke usaha pokok.

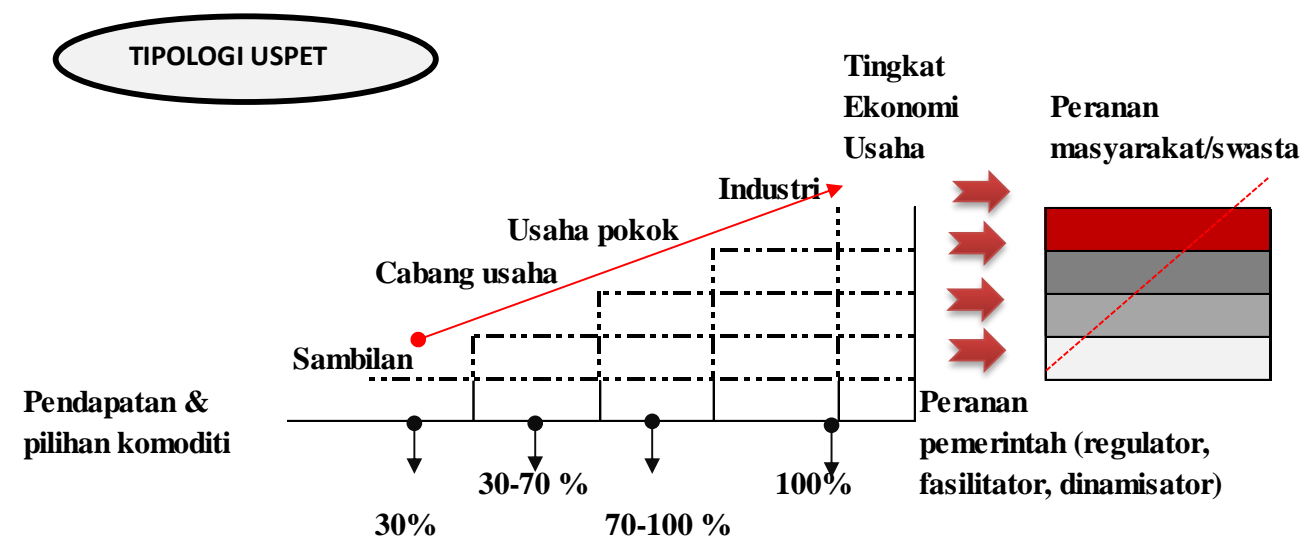

Sumber : Soehadji (1995)

Gambar 1. Tipologi Usaha Peternakan dan Tingkat Pendapatan

Untuk meningkatkan pendapatan peternak di Kabupaten Boalemo harus disertai dengan peningkatan skala usaha ternak, pengembangan pakan bahan konsentrat hijau yang murah dan berkualitas. 


\begin{tabular}{llll}
\hline Peningkatan skala usaha ternak & di dalam negeri oleh peternak kecil, \\
tentunya harus memperhatikan & sedangkan produksi sapi bakalan sangat \\
kelahiran ternak. Keberhasilan dari & dipengaruhi oleh problem dan prospek \\
usaha pembibitan ditentukan dari & usaha pembibitan. Usaha sapi potong \\
kemampuan reproduksi sapi yang & pada pola pembibitan di kelompok tani \\
dipelihara. Umumna peternak & memperlihatkan hasil yang belum \\
menggunakan teknik reproduksi berupa & optimal.
\end{tabular}
perkawinan alami dan inseminasi buatan karena mendapat bantuan dari dinas setempat. Hasil penelitian Ekowati (2012) bahwa peternak mengelola usaha ternaknya dengan skala rata-rata 4,94 ekor atau 4,07 ST dapat memberikan hasil sebesar Rp1.934.861,713,-per tahun. Faktor yang dapat meningkatkan produksi sapi potong adalah jumlah induk, curahan waktu kerja, service per conception, jumlah pakan hijauan, jumlah pakan tambahan, pengalaman beternak dan penerapan agribisnis. Penelitian Noryadi (2014), bahwa skala pemeliharaan sapi potong di Kabupaten Garut yaitu 5-6 ekor diperoleh pendapatan atau keuntungan lebih besar daripada memelihara sapi pada skala 12 ekor dan 3-4 ekor. Pendapatan ratarata peternak sapi $\mathrm{Rp} 1.687 .085$ per bulan. Penghasilan tersebut diatas Upah Minimum Kabapaten (UMK) Kabupaten Garut sebesar Rp 1.085.000 per bulan yang ditetapkan Gubernur Jawa Barat tahun 2014. Dalam memaksimalkan keuntungan (penghasilan) yang optimal maka pengkajian terhadap penggunaan input yang optimal sangat diperlukan. Adapun penggunaan input optimal, berat optimal sapi bakalan seberat 185 $\mathrm{kg}$. Jika penambahan berat sapi optimal sebesar 1,2 kg/hari dengan lama penggemukan selama 225 hari maka dibutuhkan pakan bahan konsentrat secara optimal sebesar $9 \mathrm{~kg} / \mathrm{hari}$ dan pemberian pakan hijauan oleh peternak rata-rata sebanyak $24 \mathrm{~kg} /$ hari.

Hadi dan Ilham (2002)

88 melaporkan bahwa sumber utama sapi bakalan untuk usaha penggemukan adalah kegiatan pembibitan sapi potong 
Tabel 5. Koefisien Variabel Penduga

Pendapatan Kelompok dan Non Kelompok Peternak Sapi Potong di

Kecamatan Wonosari Kabupaten Boalemo

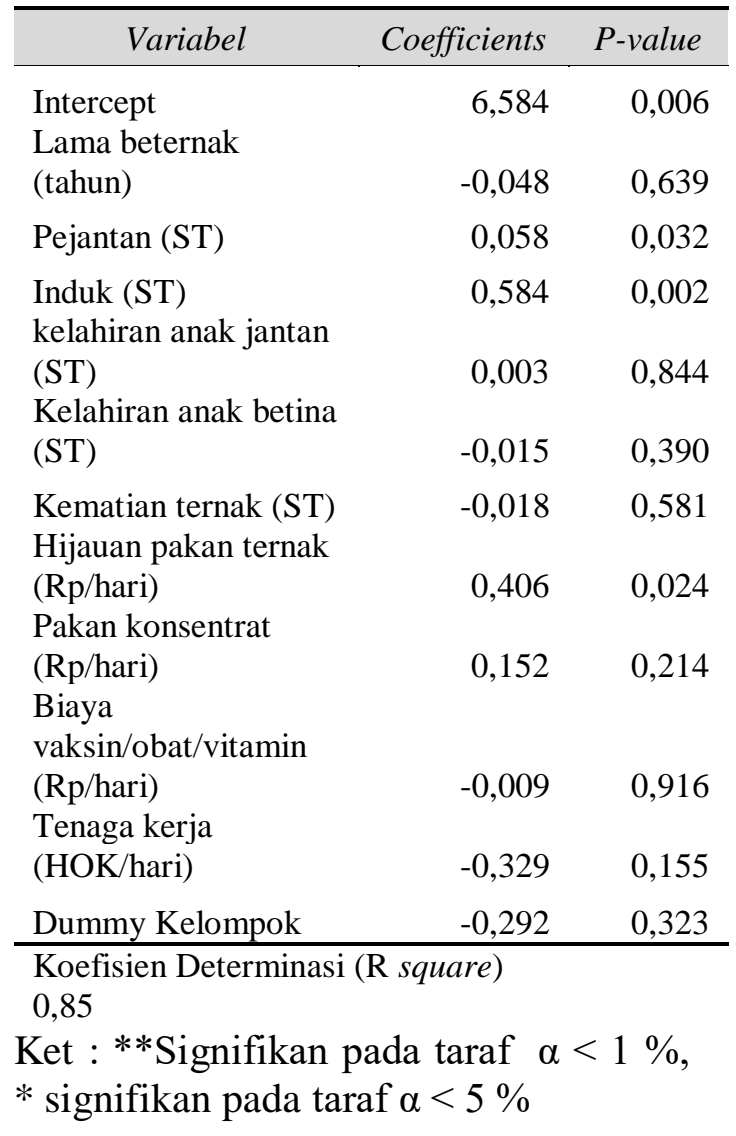

Dari Tabel 5 diketahui bahwa koefisien variabel penduga pendapatan anggota kelompok peternak sapi potong yang mempunyai pengaruh yang kuat dalam menunjang keberhasilan usaha pembibitan sapi Bali yaitu jumlah induk yang berpengaruh sangat nyata sekitar 99 persen, signifikan pada taraf $\alpha<1$ $\%$ mempengaruhi pendapatan, dan 95 persen berpengaruh terhadap jumlah pejantan serta pemberian pakan hijauan dengan signifikansi pada taraf $\alpha<5 \%$. $\mathrm{R}$ Square 85 persen mempengaruhi variabel independent, sedangkan 15 persen dipengaruhi dari faktor luar. Adapun variabel-variabel penduga pendapatan adalah sebagai berikut:
1. Induk

Variabel jumlah induk (sapi betina dewasa) memiliki nilai $P$-value 0,002 artinya variabel ini berpengaruh sangat nyata terhadap model pada taraf $\alpha \leq 1 \%$. Koefisien variabel bertanda positif (+), yang artinya semakin tinggi jumlah induk yang dimiliki, maka pendapatan usaha pembibitan sapi akan semakin meningkat. Nilai koefisien sebesar 0,584 yang artinya jika jumlah induk sapi meningkat sebesar satu persen, maka diduga nilai pendapatan usaha pembibitan sapi meningkat sebesar 0,584 persen dengan asumsi cateris paribus.

Berdasarkan wawancara dengan peternak sapi potong jumlah induk sapi yang mereka pelihara bervariasi antara $1-2$ ekor. Dalam kelompok biasanya dipelihara 10-20 ekor induk sapi yang dibagi rata ke anggota kelompok yang berjumlah 10 orang masing-masing memperoleh 1-2 ekor induk.

Kelompok peternak sangat berperan dalam pengembangan sapi potong terutama dalam pemeliharaan induk untuk menghasilkan bibit yang berkualitas. Rendahnya kualitas induk sapi berpengaruh terhadap kontinuitas produksi sumber bibit. Menurut Rianto dan Purbowati (2013) bahwa pemotongan sapi betina yang memiliki kondisi baik dan induk/betina produktif mencapai 40 persen. Hal ini akan berdampak langsung pada terjadinya seleksi negatif dan kecenderungan penurunan mutu genetik sapi serta performans reproduksi yang rendah.

\section{Pejantan}

Variabel pejantan memiliki nilai $P$-value 0,032 artinya variabel ini berpengaruh sangat nyata terhadap model pada taraf $\alpha \leq 5 \%$. Koefisien variabel bertanda positif (+), yang artinya semakin banyak jumlah pejantan yang dimiliki, maka pendapatan usaha pembibitan sapi akan semakin meningkat. Nilai koefisien sebesar 
0,058 yang artinya jika pendapatan pembibitan sapi meningkat sebesar satu persen, maka diduga nilai keuntungan pembibitan sapi meningkat sebesar 0,058 persen dengan asumsi cateris paribus.

Pada kelompok peternak jumlah pejantan yang dimiliki 1 ekor. 1 ekor pejantan dapat dikawinkan sekitar 10 induk betina agar diperoleh keturunan. Namun dengan kemajuan teknologi, peternak telah menerapkan inseminasi buatan pada ternak. Pejantan akan lebih cepat tumbuh atau mempunyai pertambahan bobot badan yang lebih tinggi dibandingkan sapi betina. Oleh karena itu, para peternak/kelompok peternak lebih menyukai pejantan sebagai bakalan dalam usaha penggemukan. Kepemilikan ternak jantan di kelompok dipelihara sebagai tabungan, dan sewaktu-waktu dijual untuk memenuhi kebutuhan keluarga.

\section{Kelahiran ternak}

Variabel kelahiran anak jantan memiliki nilai $P$-value 0,844 artinya variabel ini tidak berpengaruh nyata terhadap model. Kelahiran akan meningkatkan jumlah populasi ternak, baik untuk pembibitan, penggemukan dan tenaga kerja ternak yang mengakibatkan keberhasilan dan peningkatan pendapatan. Kelahiran ternak tidak berpengaruh pada model, hal ini dikarenakan rendahnya kelahiran anak jantan pada usaha ternak sapi potong. Koefisien variabel bertanda positif (+), yang artinya semakin besar jumlah kelahiran anak jantan, maka pendapatan usaha pembibitan sapi akan semakin meningkat. Nilai koefisien sebesar 0,003 yang artinya jika pendapatan usaha pembibitan sapi meningkat sebesar satu persen, maka diduga nilai pendapatan pembibitan sapi meningkat sebesar 0,003 persen dengan asumsi cateris paribus.

Variabel kelahiran anak betina memiliki nilai $P$-value 0,390 artinya variabel ini tidak berpengaruh nyata terhadap model. Koefisien variabel bertanda negatif (-), yang artinya rendahnya kelahiran ternak betina pada pemeliharaan sapi potong. Semakin besar jumlah kelahiran anak betina, maka pendapatan usaha pembibitan sapi akan semakin meningkat. Namun melihat kondisi di lapangan kelahiran ternak betina sangat rendah, yang dipengaruhi oleh beberapa faktor baik feeding, breeding dan manajemen. Rendahnya kelahiran ternak diakibatkan umur sapih mencapai 6 bulan Kelompok peternak belum memahami waktu penyapihan pada pedet yang seharusnya sekitar 4 bulan. Dengan umur sapih 6 bulan mengakibatkan induk lambat untuk bunting.

\section{Kematian ternak}

Variabel kematian ternak memiliki nilai $P$-value 0,581 artinya variabel ini tidak berpengaruh nyata terhadap model pada taraf signifikansi $5 \%$. Koefisien variabel bertanda negatif (-), yang artinya semakin besar jumlah kematian sapi, maka pendapatan usaha pembibitan sapi akan semakin menurun. Nilai koefisien sebesar 0,018 yang artinya jika kematian sapi meningkat sebesar satu persen, maka diduga nilai pendapatan pembibitan sapi akan menurun sebesar 0,018 persen dengan asumsi cateris paribus. Kematian ternak dapat disebabkan oleh penyakit, kekurangan pakan baik yang bersumber dari hijauan maupun pakan konsentrat dari dedak/konga, jagung, dan hasil limbah pertanian. Selain itu kematian dapat disebabkan oleh penyakit brucellosis, yang disebabkan oleh kekurangan nutrisi.

\section{Hijauan pakan ternak}

Variabel hijauan pakan ternak memiliki nilai $P$-value 0,024 artinya variabel ini berpengaruh nyata terhadap model pada taraf $\alpha \leq 5 \%$. Untuk usaha pembibitan ternak maupun 
penggemukan diperlukan pakan hijauan yang melimpah, pada pola pemberian pakan hijauan di peternak sapi potong, pakan hijauan diberikan secara ad libitum yang didukung dengan padang penggembalaan yang luas dan sebagian peternak mendapatkan sumber hijauan dari penanaman bibit rumput gajah. Koefisien variabel bertanda negatif $(+)$, yang artinya semakin tinggi pakan hijauan yang diberikan kepada ternak, maka pertambahan berat badan akan semakin meningkat, maka pendapatan usaha pembibitan sapi akan meningkat.

Menurut Abdullah (2014), pakan hijauan merupakan menu utama bagi ternak ruminansia dengan konsumsi harian mencapai 70 persen dari total ransum. Secara teknis pakan hijauan sangat berperan dalam menjaga kesehatan dan fungsi rumen. Ketersediaan pakan hijauan dalam ransum ruminansia adalah mutlak diperlukan. Kekurangan hijauan pakan di beberapa peternakan sapi telah menyebabkan umur produktif lebih pendek yang seharusnya 6-7 tahun menjadi 3-4 tahun, banyak sapi induk yang gagal reproduksi karena penimbunan lemak pada sistem reproduksi akibat kompensasi hijauan oleh konsentrat, sehingga peternak harus mengganti dengan sapi yang baru. Hal inilah yang menyebabkan investasi pada usaha ternak sapi (khususnya sapi perah) menjadi mahal dan membebani peternak, karena replacement rate bibit sangat tinggi, padahal stok bibit tidak mencukupi, ketersediaan pakan hijauan menjadi faktor penentu perkembangan usaha ternak sapi.

Penggunaan hijauan pakan sebagai menu utama dalam ransum sapi dapat mengurangi biaya pakan, seperti pemeliharaan di padang penggembalaan. Pemeliharaan sapi pada sistem penggembalaan di Australia untuk pembesaran memerlukan biaya pakan AUS \$ 2.8 (Rp30.240) per minggu, dibandingkan dengan pemeliharaan/pembesaran sapi (bukan penggemukan) secara intensif di pulau Jawa mencapai Rp9.045-14.500 per hari atau rata-rata menghabiskan biaya pakan Rp84.500 per minggu. Hal inilah yang menyebabkan harga sapi dan daging di Australia lebih murah dibandingkan di Indonesia (Abdullah 2014).

\section{Pakan konsentrat}

Variabel pakan konsentrat memiliki nilai $P$-value 0,214 artinya variabel ini tidak berpengaruh nyata terhadap model pada taraf $\alpha \leq 5 \%$. Pada umumnya peternak sapi potong memberikan pakan konsentrat berupa dedak/konga, jagung giling/pucuk jagung hasil pertanian, pucuk tebu serta kulit kakao. Pakan konsentrat ini mudah diperoleh karena cukup tersedia, yang menjadi kendala pengolahan pakan konsentrat karena diberikan kepada ternak tanpa ada proses pegolahan. Sedangkan konsentrat pabrikan yang terdapat mineral dan zat nutrisi lainnya cukup sulit diperoleh, dan jarang diberikan karena harganya cukup mahal. Usaha ternak sapi potong yang diarahkan untuk pembibitan ternak kurang memperhatikan pemberian konsentrat, padahal untuk meningkatkan mutu ternak diperlukan makanan tambahan dalam ransum sapi potong.

Upaya alternatif untuk mengurangi ketergantungan bahan baku konsentrat yang bersumber dari serealia, biji-bijian dan limbah agroindustri terutama dari hasil import adalah mengoptimalkan pemanfaatan hijauan pakan berkualitas tinggi dari tanaman pakan Leguminoseae atau dikenal dengan nama legum. Penggunaan hijauan berkualitas tinggi berpeluang untuk menerapkan sistem produksi ternak organik serta mengurangi ketergantungan bahan baku impor. Hal inilah yang mendorong Australia mengembangkan areal lamtoro hingga 
mencapai 200.000 ha, karena di negara Australia bahan konsentrat konvensional semakin hari semakin mahal akibat berkembangnya industri berbasis biorefinary. Australia terus berupaya melakukan peningkatan efisiensi produksi terutama dalam penyediaan pakan dengan memanfaatkan sumberdaya lokal dalam skala industri (McSweeney et al 2011 dalam Abdullah 2014).

Penggunaan legum pakan Lamtoro di Indonesia telah sukses dilakukan di Amarasi Provinsi Nusa Tenggara Timur. Hasil kajian selama musim kemarau di desa Merbaun Kecamatan Amarasi Barat dan desa Oesena Kecamatan Amarasi Kabupaten Kupang menunjukkan bahwa penggunaan daun lamtoro masingmasing $72 \%$ dan $53 \%$ dalam ransum dapat menghasilkan pertambahan bobot badan harian sapi bali masing-masing $0,74 \mathrm{~kg} / \mathrm{hari}$ dan 0,76 kg/hari (Lani 2014 dalam Abdullah 2014), lebih tinggi 0,2-0,26 kg dari sapi bali dengan pemeliharaan di desa lain yang tidak berbasis legum. Fungsi konsentrat pada ransum ternak adalah sebagai penguat untuk mengoreksi kekurangan nutrisi pada ransum yang diberikan agar dapat memenuhi kebutuhan untuk hidup (maintenance), produksi dan reproduksi (Abdullah 2014).

\section{Biaya vaksin, obat dan vitamin}

Variabel obat dan vaksin memiliki nilai $P$-value 0,916 artinya variabel ini tidak berpengaruh nyata terhadap model. Koefisien variabel bertanda negatif (-), pada umumnya peternak kurang memperhatikan pemberian obat, vaksin dan vitamin. Hal ini dikarenakan sistem pemeliharaan ekstensif, kebanyakan ternak digembalakan di padang penggembalaan, sehingga pemberian 92 obat vaksin hanya melihat kondisi ternak dan kurang terpantau. Biasanya terdapat pengobatan gratis dari instansi terkait jadi mengurangi biaya vaksin obat dan vitamin. Nilai koefisien sebesar 0,009 yang artinya biaya untuk membeli obat dan vaksin meningkat sebesar satu persen, maka diduga nilai pendapatan pembibitan sapi akan berkurang sebesar 0,009 persen dengan asumsi cateris paribus.

\section{Tenaga kerja}

Variabel tenaga kerja memiliki nilai $P$-value 0,155 artinya variabel ini tidak berpengaruh nyata terhadap model. Koefisien variabel bertanda negatif (-) yaitu sebesar 0,329 yang artinya penggunaan tenaga kerja pada usaha ternak sapi potong kurang efisien. Rata-rata penggunaan tenaga kerja peternak sapi potong sekitar 0,211 HOK/UT. Peternak memiliki rata-rata curahan tenaga kerja pada usaha ternak sapi 236,56 HOK/tahun Curahan tenaga kerja banyak digunakan untuk mencari pakan, membersihkan kandang, memberi pakan, memberi minum dan mengandangkan sapi. Pada penelitian Sani et al (2010) bahwa rata-rata curahan tenaga kerja keluarga untuk peternak transmigran di Usaha ternak sapi mencapai 262,91 HOK/tahun, dan peternak lokal 188,49 HOK/tahun. Hasil penelitian Hartono (2005) dalam Sani et al (2010) bahwa Usaha ternak sapi perah dengan skala usaha rata-rata 3,6 UT dan 7,4 UT menghasilkan ratarata curahan tenaga kerja keluarga 102,05 HOK/tahun dan 124,43 HOK/tahun, yang berarti bahwa semakin banyak sapi yang dipelihara maka curahan tenaga kerja keluarga semakin efisien.

\section{Kelompok peternak (Kelompok peternak dummy)}

Variabel dummy kelompok memiliki nilai $P$-value 0,323 artinya variabel ini tidak berpengaruh nyata terhadap model pada taraf signifikansi 5 persen. Koefisien variabel bertanda negatif (-) yaitu sebesar 0,292 yang 
artinya keikutsertaan anggota peternak dalam kelompok belum memberikan hasil yang optimal. Keikutsertaan peternak dalam kelompok tidak memberikan pengaruh, terutama dalam peningkatan pendapatan usaha ternak sapi potong. Menurut Yunasaf (2008) Bahwa tidak berdaya atau berkualitasnya petani karena tidak berdayanya kelembagaan petani, yaitu kelompoktani/ternak. Tidak berdayanya kelompoktani dapat disebabkan antara lain oleh: (1) strategi dan orientasi pembangunan pertanian belum ditujukan pada upaya mensejahterahkan dan meningkatkan pendapatan peternak. Peternak sering disuruh berproduksi, tetapi manakala menjual hasil, peternak tidak diberi kemampuan untuk menetapkan harga jual. Kelompokternakpun belum mampu berfungsi sebagai kekuatan untuk meningkatkan posisi tawar (bargaining); (2) politik pemberdayaan peternak yang dikucurkan oleh pemerintah bersifat tidak lengkap. Prioritas pembinaan lebih diarahkan pada tanaman pangan, khususnya padi, dan tanaman perkebunan (kakao), peternak masih terabaikan. Kelompokternak yang ada berfungsi tidak lebih sebagai wadah penyalur sarana produksi atau sebatas sebagai objek kebijakan; (3) pola dan arah pembinaan kelompok lebih banyak menjadikan peternak sebagai kelompok binaan pencapaian target produksi. Kelompok dipandang hanya sebagai wadah untuk memudahkan pekerjaan penyuluh mendifusikan inovasi. Tidak ada prioritas strategi pembinaan agar kelompok menjadi dinamis dan mandiri; dan (4) pembinaan kelompok lebih banyak diarahkan pada pencapaian target kuantitas bukan kualitas. Kelompokternak yang muncul atas dasar dan kebutuhan peternak sangat kecil. Falsafah pemberdayaan melalui dinamika kelompok belum menjadi prioritas penyuluhan termasuk kepemimpinan, komunikasi dan organisasi. Akibatnya peternak tidak dapat mengelola kelompok secara profesional.

Hasil penelitian Trigestianto et al (2013) bahwa peternak sapi potong di Kabupaten Purbalingga termasuk dalam kategori kurang sejahtera dengan nilai tukar pendapatan rumah tangga peternak (NTPRP) < $151.42 \%$. Hasil analisis regresi terdapat hubungan antara jumlah keluarga, dan jumlah ternak yang dipelihara terhadap kesejahteraan peternak sapi potong dengan koefisien determinasi $\left(\mathrm{R}^{2}\right)$ diperoleh sebesar 0.418. Sehingga $\mathrm{H}_{1}$ dan hipotesisnya dapat diterima. Sedangkan tingkat pendidikan, pekerjaan peternak dari hasil analisis regresi tidak berpengaruh nyata terhadap tingkat kesejahteraan peternak.

Faktor-faktor yang digunakan dalam penelitian mempunyai hubungan yang positif dan negatif terhadap peningkatan pendapatan usaha pembibitan sapi potong yang berkaitan dengan keberhasilan usaha sapi potong di Kabupaten Boalemo. Berdasarkan hasil analisis regresi nilai signifikansi jumlah kepemilikan pejantan dan induk berpengaruh terhadap pendapatan usaha ternak yang berarti bahwa jumlah kepemilikan ternak dewasa jantan dan induk menentukan keberhasilan usaha ternak sapi potong. Krisna dan Mansur (2006) menyatakan bahwa semakin tinggi skala usaha yang dijalankan dan ternak yang dimiliki maka akan semakin besar penerimaan yang akan diterima serta dapat menekan biaya produksi yang dikeluarkan. faktorfaktor yang lainnya juga perlu menjadi prioritas utama dalam suatu kebijakan melalui program pemerintah dalam meningkatkan keberhasilan usaha sapi potong pada anggota kelompok peternak.

Korelasi antara variabel penduga pendapatan dengan hasil kinerja yang diukur dengan metode importance 
performance analysis (IPA). Variabel penduga pendapatan kelompok dan non kelompok peternak sapi potong adalah jumlah induk, pejantan dan hijauan pakan ternak. Hasil IPA menunjukkan bahwa tingkat kepentingan tinggi dan kinerja rendah yaitu kemudahan memperoleh pakan konsentrat, keterampilan yang dimiliki peternak masih rendah, kesulitan memperoleh modal dan insfrastruktur sarana dan prasarana belum optimal. Apabila kinerja keempat indikator tersebut bisa ditingkatkan, maka akan berpengaruh pada pendapatan peternak sapi potong.

Peningkatan pendapatan sangat dipengaruhi oleh modal usaha. Aspek pembiayaan yang dapat membantu peternak dalam mengembangkan usaha dan meningkatkan pendapatan yaitu adanya akses kredit dan modal. Terdapat berbagai sumber pembiayaan yang dapat dimanfaatkan oleh peternak sapi potong seperti bank, koperasi, dan lain sebagainya. Namun tidak semua peternak sapi potong mendapatkan akses sumber pembiayaan tersebut. Akses kredit dan modal dapat berpengaruh dalam peningkatan pendapatan, sehingga pemerintah perlu memberikan akses dalam mempermudah memperoleh bantuan modal usaha. Kemudahan dalam memperoleh modal masih sulit diakses, masih kurangnya lembaga keuangan di Kabupaten Boalemo merupakan salah satu kendala. Sehingga kinerja dalam memperoleh modal masih rendah, akan tetapi kepentingan sangat tinggi. Untuk itu perlu diprioritaskan. Rianto (2010) menyatakan bahwa untuk meningkatkan produktivitas sapi potong adalah dengan melakukan pemberdayaan peternak melalui kegiatan penyuluhan yang diikuti dengan pendampingan serta dukungan modal. Hasil penelitian Nwaru et al. (2011) menyarankan untuk adanya implikasi kebijakan dan program pemerintah untuk meningkatkan akses petani terhadap kredit. Dengan demikian, peran serta seluruh pihak sangat diperlukan sehingga usaha sapi potong dapat berhasil dan ketergantungan terhadap sapi impor dapat dikurangi.

\section{Kinerja Kelompok Peternak Terhadap Keberhasilan Usaha Sapi Potong Di Kabupaten Boalemo}

kelompok

usaha sapi potong digunakan metode Importance Performance Analysis (IPA). Importance Performance Analysis (IPA) merupakan alat bantu yang digunakan sebagai prioritas perbaikan atribut kinerja kelompok peternak. Metode ini menunjukkan prioritas perbaikan tingkat kinerja pada masingmasing atribut dengan diagram kartesius yang terbagi menjadi empat kuadran. Posisi setiap atribut pada kuadran didapatkan dari nilai rata-rata tingkat kepentingan dan nilai rata-rata tingkat kinerja atribut pada pengukuran kelompok peternak (Tabel 6).

Berdasarkan indikator kinerja kelompok ternak yang didasarkan pada aspek-aspek peran kelompok dalam menunjang keberhasilan usaha sapi potong yaitu: 1) keamanan; 2) memperoleh hijauan makanan ternak; 3) memperoleh konsentrat/pakan tambahan; 4) keterampilan anggota kelompok; 5) penyakit (akses dokter hewan, mantri dan obat); 6) pertemuan kelompok; 7) memperoleh modal; 8) peraturan kelompok; 9) frekuensi bimbingan teknis; 10) materi bimbingan teknis; 11) perhatian pemerintah; 12) sarana dan prasarana; 13) kerjasama; 14) struktur organisasi; 15) semangat bekerja. 
Tabel 6 Hasil analisis Importance Performance Analysis (IPA) kelompok peternak sapi potong

\begin{tabular}{clcc}
\hline \multirow{2}{*}{ No Atribut } & & $\begin{array}{c}\text { Tingkat } \\
\text { Kepentingan }\end{array}$ & $\begin{array}{c}\text { Tingkat } \\
\text { Kinerja }\end{array}$ \\
\cline { 3 - 4 } & & $\begin{array}{c}\text { Mean } \\
\text { Importance } \\
\text { Score }\end{array}$ & $\begin{array}{c}\text { Mean } \\
\text { Satisfaction } \\
\text { Score }\end{array}$ \\
\hline 1 & Keamanan & 4,30 & 4,07 \\
2 & Kemudahan memperoleh hijauan pakan ternak & 4,20 & 3,60 \\
3 & Kemudahan memperoleh konsentrat & 4,10 & 3,20 \\
4 & Keterampilan anggota kelompok & 4,07 & 3,30 \\
5 & Penyakit (Akses dokter hewan,mantri \& obat) & 4,23 & 3,43 \\
6 & Pertemuan kelompok & 3,93 & 3,23 \\
7 & Memperoleh modal & 4,23 & 3,10 \\
8 & Peraturan kelompok & 4,13 & 3,40 \\
9 & Frekuensi bimbingan teknis & 3,97 & 3,13 \\
10 & Materi bimbingan teknis & 3,87 & 3,20 \\
11 & Perhatian pemerintah & 4,33 & 3,53 \\
12 & Sarana dan Prasarana & 4,27 & 3,10 \\
13 & Kerjasama & 4,07 & 3,40 \\
14 & Struktur Organisasi & 3,53 & 3,13 \\
15 & Semangat bekerja & 3,87 & 3,47 \\
\hline & Total & 4,07 & 3,35 \\
\hline
\end{tabular}

Berdasarkan indikator kinerja kelompok ternak yang didasarkan pada aspek-aspek peran kelompok dalam menunjang keberhasilan usaha sapi potong yaitu: 1) keamanan; 2) memperoleh hijauan makanan ternak; 3) memperoleh konsentrat/pakan tambahan; 4) keterampilan anggota kelompok; 5) penyakit (akses dokter hewan, mantri dan obat); 6) pertemuan kelompok; 7) memperoleh modal; 8) peraturan kelompok; 9) frekuensi bimbingan teknis; 10) materi bimbingan teknis; 11) perhatian pemerintah; 12) sarana dan prasarana; 13) kerjasama; 14) struktur organisasi; 15) semangat bekerja.

Kelompok peternak mampu memprioritaskan atribut mana yang perlu dilakukan perbaikan. Adapun nilai yang perlu diprioritaskan oleh kelompok peternak adalah atribut yang dianggap memiliki tingkat kepentingan yang tinggi oleh kelompok namun masih memiliki tingkat kinerja yang rendah. Salah satu cara untuk menentukan prioritas perbaikan atribut kinerja adalah dengan menggunakan metode Importance Performance Analysis (IPA). Metode IPA menggambarkan tingkat kinerja masingmasing atribut melalui diagram kartesius yang terbagi dalam empat kuadran.

Berdasarkan Tabel 6 dapat dilihat bahwa nilai rata-rata tingkat kepentingan adalah 4,07 dan nilai ratarata tingkat kinerja adalah 3,35. Kedua nilai ini akan menjadi garis tengah pada diagram kartesius Importance Performance Analysis (IPA), dimana tingkat kepentingan sebagai sumbu $\mathrm{Y}$ dan tingkat kinerja sebagai sumbu $\mathrm{X}$. Diagram kartesius ini terbagi menjadi empat kuadran yang masing-masing kuadran menggambarkan kondisi yang berbeda-beda. Diagram kartesius Importance Performance Analysis (IPA) kelompok peternak (Gambar 2). 


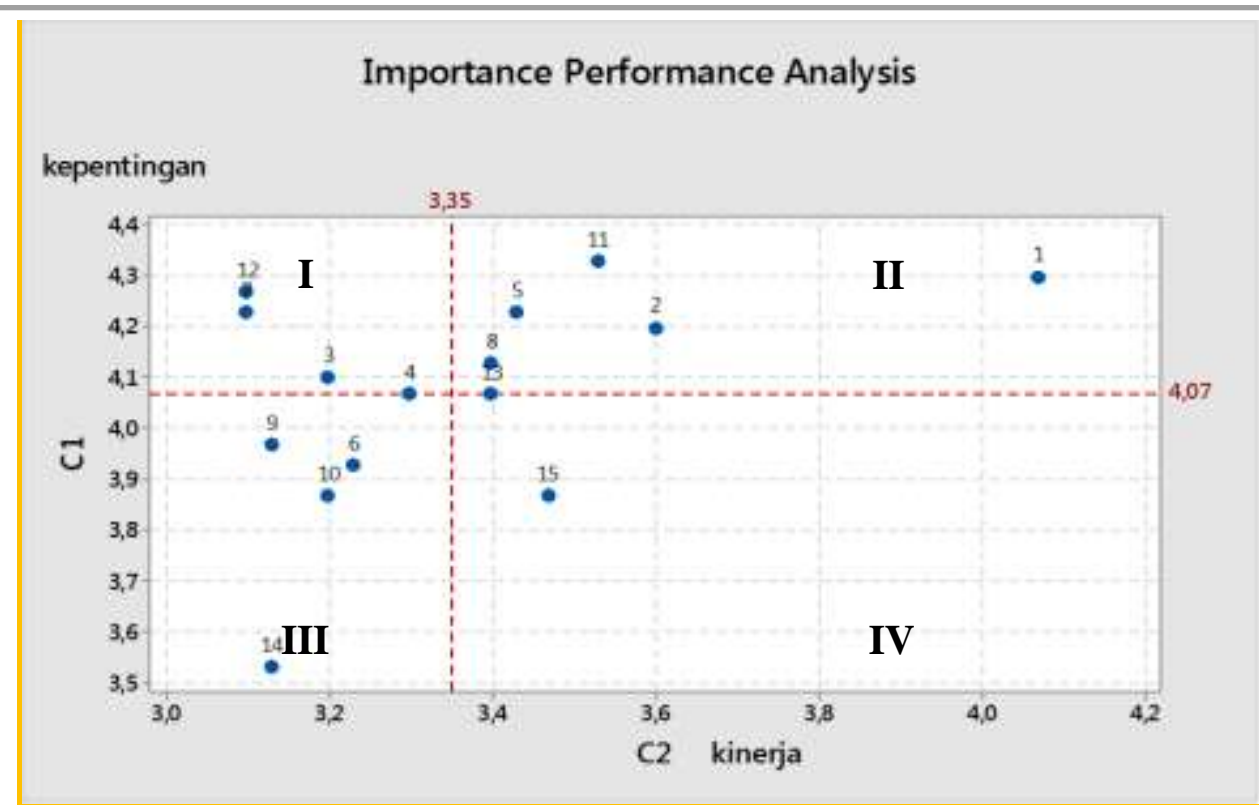

Gambar 2 Diagram Kartesius Importance Performance Analysis (IPA) Kinerja Kelompok Peternak Sapi Potong

Keterangan :

Kuadran I :

3. Kemudahan memperoleh konsentrat

4. Keterampilan anggota kelompok

7. Memperoleh modal

12. Sarana dan Prasarana

Kuadran II :

1. Keamanan

2. Kemudahan memperoleh hijauan pakan ternak

5. Penyakit (akses dokter hewan,mantri, dan obat)

8. Peraturan kelompok

11. Perhatian pemerintah

13. Kerjasama

Kuadran III :

6. Pertemuan kelompok

9. Frekuensi bimbingan teknis

10. Materi bimbingan teknis

Kuadran IV :

15. Semangat bekerja/motivasi

Berdasarkan Gambar 2 dapat dijelaskan bahwa pemetaan pada diagram kartesius berdasarkan tingkat kepentingan dan tingkat kinerja memungkinkan kelompok peternak sapi potong untuk melakukan perbaikanperbaikan atribut yang dianggap penting oleh kelompok peternak, baik dalam jangka pendek maupun dalam jangka panjang. Adanya perbaikan atribut ini dapat memudahkan kelompok peternak lebih memprioritaskan perbaikan dari setiap atributnya. Perbaikan atribut sangat bergantung pada posisi masing- masing variabel yang ada pada keempat kuadran. Korelasi antara variabel penduga pendapatan pada Tabel 10 dan rendahnya kinerja hasil IPA dapat ditingkatkan dengan peningkatan teknologi dalam breeding dari usaha sambilan menjadi usaha pokok, sehingga berpengaruh pada pendapatan.

$$
\text { Berdasarkan data hasil }
$$

perhitungan tentang kinerja kelompok peternak pada 5 desa dengan 6 kelompok peternak, yaitu kelompok pemuda karya, kelompok usaha mulya, kelompok lembu perkasa, kelompok 
winangun, kelompok lembu sari, dan kelompok maju bersama dapat diklasifikasikan dalam 5 kategori kepentingan kelompok peternak yaitu sangat tidak penting, tidak penting, cukup penting, penting dan sangat penting. Untuk 5 kategori kinerja kelompok peternak yaitu kategori sangat tidak baik, tidak baik, cukup baik, baik, serta sangat baik.

Hasil perhitungan menunjukkan bahwa kuadran I pada diagram kartesius menunjukkan tingkat kepentingan dari suatu atribut yang dianggap sangat penting oleh kelompok peternak tetapi kinerja dari atribut ini masih belum maksimal. Atribut-atribut yang berada pada Kuadran I memiliki tingkat kepentingan yang tinggi namun kinerjanya masih rendah. Hasil penelitian Firdausi et al (2014), dari hasil analisis tingkat kinerja kelompok tani serta hubungannya dengan tingkat ketahanan pangan rumah tangga petani di Kecamatan Rasanae Timur Kota Bima bahwa tingkat kinerja kelompok tani berada lebih rendah dari pada tingkat kepentingan indikator kelompok tani, sehingga tingkat kinerja kelompok tani masih berada di bawah harapan yang diinginkan petani responden. Semakin besar skor kesenjangan maka indikator tersebut harus semakin diprioritaskan untuk diperbaiki kedepannya.

\section{Kemudahan memperoleh konsentrat}

Kinerja kelompok pada atribut memperoleh konsentrat masih rendah, padahal kepentingannya sangat tinggi sehingga perlu diprioritaskan. Kepentingan dalam memperoleh konsentrat dilihat dari beberapa hal, baik cara mendapatkan pakan konsentrat, ketersediaan, dan bagaimana pengolahan pakan konsentrat.

Kebutuhan pakan sapi potong terdiri dari hijauan, leguminosa dan pakan tambahan berupa konsentrat. Hijauan dan leguminosa berfungsi sebagai sumber serat dan vitamin, dapat berupa rumput, daun-daunan, jerami, pucuk tebu, limbah jagung, limbah kulit kakao. Pakan tambahan berupa konsentrat merupakan salah satu sumber gizi tinggi, mineral dan protein (Nuschati 2008). Konsumsi pakan konsentrat yang rendah memyebabkan terjadinya defisiensi mineral, vitamin dan energi. Kekurangan pakan yang drastis dapat berakibat rendahnya skor kondisi tubuh, bobot tubuh yang seharusnya cukup untuk proses reproduksi sapi dara maupun indukan tidak cukup, dan akhirnya banyak sekali kasus reproduksi yang sumber utamanya adalah defisiensi pakan bernutrisi. Hijauan, leguminosa dan konsentrat sebaiknya diatur sedemikian rupa agar seimbang. Pemberian pakan konsentrat/tambahan sebanyak 1-2 \% dari bobot tubuh, untuk induk penggunaan konsentrat dengan $0,6-0,8$ persen protein dalam ransum. Beberapa kasus reproduksi yang sering dihadapi peternak jika terjadi defisiensi nutrisi berupa protein, energi, mineral dan vitamin adalah late estrus, silent heat hingga anestrus. Kekurangan protein menyebabkan timbulnya birahi yang lemah, berahi tenang, anestrus, kawin berulang, kematian embrio dini, absorbsi embrio yang mati oleh dinding uterus, kelahiran anak yang lemah atau kelahiran prematur. Selain pengaruh nutrisi, defisiensi dan ketidakseimbangan mineral juga berpengaruh terhadap kawin berulang, aktivitas ovarium, dan rendahnya efisiensi reproduksi (Bearden 1980 ).

Daerah Kabupaten Boalemo mempunyai suhu udara yang cukup panas yaitu berkisar antara $22,1^{\circ} \mathrm{C}$ sampai dengan $33,5^{\circ} \mathrm{C}$ dan curah hujan tertinggi $299 \mathrm{~mm}$. Dengan cuaca yang cukup panas ketersediaan pakan hijauan maupun pakan konsentrat sangat tergantung dari musim. Apabila musim penghujan, sumber hijauan dan pakan tambahan melimpah sehingga asupan 
mineral, serat dan vitamin cukup untuk ternak. Lain halnya jika musim kemarau terjadi, pakan konsentrat akan sulit ditemukan, sehingga kelompok peternak kesulitan memperoleh pakan tambahan untuk ternaknya. Salah satu cara peternak memanfaatkan melimpahnya hijauan ketika musim penghujan adalah dengan hay atau pengeringan rumput untuk menyimpannya sebagai persediaan saat sulitnya memperoleh limbah pertanian. Saat hijauan sulit ditemukan, maka pakan konsentrat adalah pilihan selanjutnya sebagai pakan. Konsentrat yang ada di pasaran terlalu mahal untuk dibeli, sehingga sebagian kelompok peternak memanfaatkan limbah pertanian sebagai bahan konsentrat buatan. Upaya mengoptimalkan pemanfaatan limbah pertanian dilakukan dengan pencincangan pada jerami jagung dan pucuk tebu, dedak/bekatul/konga serta pemanfaatan limbah kulit kakao. Untuk memperoleh konsentrat buatan pabrik masih sulit diperoleh. Pengolahan pakan konsentrat seperti limbah kulit kakao, pucuk tebu juga masih sulit dilakukan.

Pada sebagian daerah di Provinsi Gorontalo, kesulitan dalam memperoleh pakan tambahan/pakan konsentrat diantisipasi dengan program dari Departemen Pertanian melalui Direktorat jenderal PPHP (Pengolahan dan Pemasaran Hasil Pertanian) yaitu dengan pembangunan pabrik pakan ternak skala kecil (PPTSK). Di Kabupaten Boalemo sendiri belum mendapatkan alokasi dana bantuan tersebut, sehingga dengan ditetapkannya Kecamatan Wonosari sebagai pusat perbibitan sapi Bali (VBC) diharapkan pemerintah melalui Dinas Peternakan dan Perkebunan Provinsi Gorontalo melihat potensi pengembangan usaha sapi potong yang

\section{Keterampilan anggota kelompok peternak}

Pada atribut keterampilan anggota peternak sapi potong dalam kelompok dinilai kinerjanya masih rendah, namun kepentingannya sangat tinggi sehingga perlu diprioritaskan. Keterampilan anggota kelompok seperti manajemen pakan, manajemen pemeliharaan, manajemen kesehatan, manajemen reproduksi/perkawinan sangat perlu ditingkatkan. Keterampilan dalam manajemen pakan sangat berkaitan dengan peningkatan berat badan ternak. Keterampilan dalam manajemen pemeliharaan, kesehatan, reproduksi akan meningkatkan produktivitas ternak sapi potong. Untuk itu keterampilan anggota kelompok perlu ditingkatkan melalui pembinaan. Selama ini, pembinaan yang dilakukan oleh pemerintah kurang menyentuh aspek teknis di lapangan. Sehingga perlu pembinaan secara langsung ke kelompok peternak agar dapat menunjang keberhasilan usaha sapi potong.

Beberapa cara mengukur kinerja

adalah: (1) produktivitas,

keuntungan usaha yang diperoleh dan (3) kinerja administrasi, kinerja operasi dan kinerja strategik (Riyanti 2003). Hasil penelitian Harijati (2007) menemukan bahwa peningkatan kinerja peternak dipengaruhi oleh peningkatan pengetahuan, sikap dan keterampilan petani. Peternak dapat memiliki kinerja lebih baik, jika memiliki kompetensi yang tinggi. Sedangkan kegiatan penyuluhan adalah upaya peningkatan pengetahuan, sikap dan keterampilan peternak dan sebagai strategi pemberdayaan peternak.

\section{Memperoleh Modal Dalam Usaha Peternakan Sapi Potong}

Memperoleh modal mempunyai kepentingan yang sangat tinggi namun kenyataan kinerja sangat rendah. Modal merupakan salah satu faktor penting 
dalam usaha sapi potong. Usaha sapi potong tidak hanya terkait dengan kepemilikan di tingkat kelompok, melainkan memerlukan keterlibatan peran dari semua pihak yang terkait, mulai dari pelaku usaha (mitra usaha, koperasi/lokal champion, kelompok peternak), pemerintah daerah selaku pengambil kebijakan, termasuk peran perbankan dalam penyediaan pembiayaan.

$$
\text { Pengalaman membuktikan, }
$$

bahwa membangun kemitraan usaha kecil dengan mitra usaha (menengah/besar) bukanlah hal yang mudah dilakukan dan memerlukan upaya terus-menerus agar dapat berkembang sesuai harapan. Peran dari Pemerintah Daerah menjadi sangat penting dan diharapkan dapat menfasilitasi sebanyak mungkin pembentukan dan penguatan kemitraan melalui kelompok peternak dengan pendekatan klaster sebagai embrio untuk memudahkan pembentukan kemitraan usaha sapi potong. Dalam pelaksanaan program kegiatan melibatkan peran 3 stakeholder, yaitu: 1) Pemerintah Daerah, sebagai motor penggerak dalam pembangunan perekonomian di daerah; 2) Pengusaha (UMKM), sebagai investor/pelaku usaha yang melakukan kegiatan ekonomi; 3) Lembaga keuangan (perbankan), sebagai pendukung dalam pembiayaan usaha. Lembaga pembiayaan (perbankan) sebagai pemberi pinjaman/kredit.

Namun dalam memperoleh modal, pihak perbankan tentu saja tidak mudah memberikan bantuan. Sulitnya memperoleh modal tidak didukung oleh kesiapan/persyaratan dari kelompok peternak sapi potong. Kelompok peternak yang tergabung dalam kerjasama kemitraan usaha harus menjadi anggota koperasi. Koperasi ini bisa melakukan kegiatan-kegiatan untuk membantu kelompok peternak di dalam mempersiapkan dan menjalankan usahanya, khususnya untuk pengurusan kredit ke bank. Dalam hal ini koperasi dapat bertindak sebagai BDS-P/KKMB yang membantu kelompok-kelompok peternak untuk mendapatkan pembiayaan dari lembaga keuangan (perbankan).

Bank dapat memberikan pembiayaan investasi dan modal kerja dalam rangka pengembangan usaha sapi potong melalui kelompok peternak. Skim pembiayaan yang ditentukan berdasarkan besarnya tingkat suku bunga yang sesuai dengan bentuk usaha yang dikembangkan, sehingga kelompok peternak dapat memperoleh manfaat yang besar dari pembiayaan yang diberikan. Bank juga harus menentukan sistem pencairan kredit, penggunaan kredit, dan sistem pembayaran angsuran pokok pinjaman beserta bunganya yang disesuaikan dengan cash flow peternak.

Pembiayaan untuk menambah modal bagi peternak sapi potong yaitu KUR (Kredit Usaha Rakyat) dan KKPE (Pembiayaan/kredit Ketahanan Pangan dan Energi). Peserta KKP-E adalah peternak yang tergabung dalam kelompok peternak dan menjadi anggota koperasi yang secara mandiri atau bersama-sama bekerjasama dengan mitra usaha.

\section{Infrastruktur Sarana Dan Prasarana Pendukung Peternakan}

Sarana dan prasarana terletak di kuadran I pada diagram kartesius menunjukkan bahwa tingkat kepentingan dianggap sangat penting oleh kelompok peternak tetapi kinerja belum maksimal. Ketersediaan sarana dan prasarana pendukung usaha peternakan sapi potong seperti pasar hewan, RPH/TPH (Rumah pemotongan hewan), petugas kesehatan, dokter hewan, masih terbatas. Pasar hewan sudah mulai dibangun di Desa Harapan Kecamatan Wonosari. Untuk RPH sampai saat ini di wilayah Kabupaten 
Boalemo belum ada. Sehingga sarana dan prasarana pendukung peternakan sangat dibutuhkan oleh peternak sapi potong perlu dipriotaskan.

Dalam merumuskan alternatif strategi dapat berdasarkan hasil dari metode Importance Performance Analysis (IPA) dengan melihat kuadran pertama yang menjadi prioritas dan dengan wawancara pemangku kebijakan dan mengaitkan dengan strategi kebijakan yang sudah ada selama ini dan kemudian perlu dilanjutkan kembali dengan mengacu kepada program kegiatan yang ada instansi terkait.

\section{SIMPULAN DAN SARAN}

\section{Simpulan}

1. Faktor-faktor yang mempengaruhi pendapatan kelompok peternak sapi potong yaitu jumlah pejantan, induk/betina dewasa dan hijauan makanan ternak. Sedangkan faktorfaktor yang tidak berpengaruh yaitu jumlah kelahiran ternak, pakan konsentrat, ketersediaan obat,vaksin,vitamin dan dummy kelompok, sehingga perlu meningkatkan peran kelompok peternak.

2. Atribut-atribut yang memiliki tingkat kepentingan tinggi namun kinerjanya masih rendah, yaitu memperoleh pakan konsentrat, keterampilan anggota kelompok, fasilitas sarana dan prasarana pendukung peternakan serta masih sulitnya memperoleh modal dalam usaha sapi potong, penanganan atribut tersebut perlu diprioritaskan.

\section{Saran}

1. Strategi kebijakan berdasarkan hasil analisis Importance Performance Analysis (IPA), yaitu:

a) Memperoleh pakan konsentrat melalui strategi meningkatkan kualitas input dan output produksi melalui pemanfaatan teknologi.

b) Keterampilan anggota kelompok melalui strategi meningkatkan teknik budidaya, pemeliharaan dan pengelolaan usaha sapi potong.

c) Mengoptimalkan sarana dan prasarana pendukung peternakan.

d) Menfasilitasi kemudahan permodalan pengembangan usaha peternakan sapi potong.

e) Pengembangan kelembagaan kelompok peternak sapi potong

2. Pemeliharaan sapi potong pada kelompok ternak ditujukan untuk menghasilkan pedet dan bakalan. Dukungan dari pemerintah berupa kebijakan-kebijakan yang tepat sasaran agar kelompokternak dapat menjalankan perannya dengan baik, yaitu: terbentuknya kelompok peternak dengan manajemen yang memadai disertai pendampingan dari dinas terkait.

\section{DAFTAR PUSTAKA}

Abdullah L. 2014. Mewujudkan Konsentrat Hijau (Green Concentrate) dalam Industri Baru Pakan untuk Mendorong Kemandirian Pakan dan Daya Saing Peternakan Nasional. Institut Pertanian Bogor, Bogor.

Bearden HJ, John W, Fuquay. 1980. Applied Animal Reproduction Reston Publisihing Company. Inc. A. Printice Hall Company Reston Virginia.

Badan Pusat Statistik. 2013. Gorontalo dalam Angka. BPS Provinsi Gorontalo. Gorontalo 2013. Boalemo Dalam Angka. Badan Pusat Statistik Kabupaten Boalemo. Boalemo.

Direktorat Jenderal Peternakan. 2013. Populasi Sapi Potong. 
[Internet]. [diunduh 2013 Des

10] Tersedia pada: http://www.deptan.go.id/infoeks ekutif/nak/pdfeisNAK2013/Pop_SapiPotong_ Prop_2013.pdf

Ekowati T. 2012. Analisis Usaha Ternak Sapi Potong dan Optimalisasi Usaha Peternakan Berbasis Sistem Agribisnis di Jawa Tengah . [Disertasi] Program Pascasarjana Fakultas Pertanian Universitas Gadjah Mada Yogyakarta Nomor: 08/276234/SPN/00359.

Firdausi A, Koestiono D, Muhaimin AW. 2014. Analisis Tingkat Kinerja Kelompok Tani Sera Hubungannya dengan Tingkat Ketahanan Pangan Rumah Tangga Petani (Studi Kasus di Kecamatan Rasanae Timur Kota Bima). Jurnal Agrise, Mei 2014, Vol.XIV No.2. ISSN: 14121425.

Harijati S. 2007. Potensi dan Pengembangan Kompetensi Agribisnis Petani Berlahan Sempit : Kasus Petani Sayuran di Kota dan Pinggiran Jakarta dan Bandung. Disertasi, IPB.

Hoddi AH, Rombe MB, Fahrul. Analisis Pendapatan Peternakan Sapi Potong di Kecamatan Tanete Rilau Kabupaten Barru. Jurnal Agribisnis Vol.X No 3 September 2011. Fakultas Peternakan Universitas Hasanuddin Makassar.

Hadi PU, Ilham N. 2002. Problem dan Prospek Pengembangan Usaha Pembibitan Sapi Potong di Indonesia. Jurnal Litbang Pertanian Vol.21 (4). Badan Litbang Pertanian. Bogor.

Krisna R, Mansur E. 2006. Tingkat Pemilikan Sapi (Skala Usaha) Peternakan dan Hubungannya dengan Keuntungan Usahatani Ternak Pada Kelompok Tani
Ternak Sapi Perah di Desa Tajur Halang Bogor. Jurnal Penyuluhan Pertanian Vol.1 No.1, Mei 2006. Jurusan Penyuluhan Peternakan STPP Bogor.

Kusdianawati 2012. Analisis Kepuasan Peternak Sapi Potong terhadap Pelayanan Kesehatan Hewan Dinas Peternakan di Desa Timurung Kecamatan Ajangale Kabupaten Bone. [Skripsi] Fakultas Peternakan Universitas Hasanuddin Makassar.

Muhsis A. 2007. Peran Kelompok Peternak dan Prospek Usaha Penggemukan Sapi Potong. Seminar Nasional Teknologi Peternakan dan Veteriner. Magelang, Jawa Tengah.

Nuschati U. 2008. Teknologi Formulasi Ransum untuk Penggemukan Sapi pada Wilayah Marjinal.

Riyanti BPD. 2003. Kewirausahaan dari Sudut Pandang Psikologi Kepribadian. Jakarta : PT Gramedia.

Rahmanto B. 2004. Analisis Usaha Peternakan Sapi Potong Rakyat. Pusat Penelitian dan Pengembangan Sosial Ekonomi Pertanian. Icaserd Working Paper No.59 No Dok. 062.59.8.04. Bogor.

Rangkuti F. 2006. Measuring Customer Satisfaction : (Gaining Customer Relationship Strategy) Teknik Mengukur dan Strategi Meningkatkan Kepuasan Pelanggan \& Analisis Kasus PLN-JP). Jakarta : PT Gramedia Pustaka Utama.

Tawaf R, Kuswaryan S. 2006. Kendala Kecukupan Daging $2010 \mathrm{hlm}$ 173-185 Dalam Sukanto B, Rianto E, Legowo AM. Pemberdayaan Masyarakat Peternakan di Bidang Agribisnis untuk Mendukung Ketahanan Pangan. Prosiding Seminar 
nasional 2006. Semarang : Universitas Diponegoro.

Trigestianto $M$, Nur S, Sugiarto $M$. 2013. Analisis Tingkat Kesejahteraan Peternak Sapi Potong di Kabupaten Purbalingga. Jurnal Ilmiah Peternakan 1 (3): 1158-1164 September 2013. Fakultas Peternakan Universitas Jenderal Soedirman.

Umar H. 2005. Riset Pemasaran dan Perilaku Konsumen. Jakarta: PT Gramedia Pustaka Utama.

Yunasaf U (2008). Keberdayaan Kelompoktani dan Hubungannya dengan Keberhasilan Usahatani Anggota Kelompok tani Sapi Perah di Kabupaten Sumedang. Laporan Penelitian (Penelitian Peneliti Muda (LITMUD) Universitas Padjajaran. Jawa Barat. 